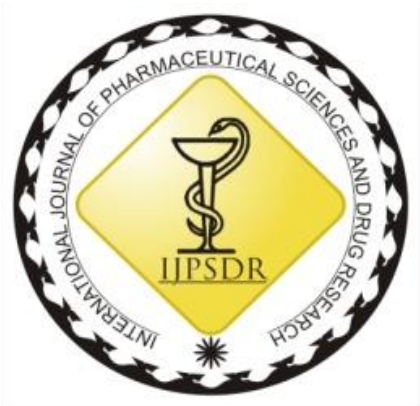

ISSN: 0975-248X

RESEARCH ARTICLE CODEN (USA): IJPSPP $($ (c) $)$ EY-NC-SA

\title{
Sand Dune Streptomyces JB66 Native to the Great Indian Thar Desert Inhibits Multidrug-Resistant Pathogens
}

\author{
Jyotsna Begani ${ }^{1}$, Jyoti Lakhani², Dharmesh Harwani ${ }^{1 *}$ \\ ${ }_{1}^{1}$ Department of Microbiology, Maharaja Ganga Singh University, Bikaner-334001, Rajasthan, India \\ ${ }_{2}^{2}$ Department of Computer Science, Maharaja Ganga Singh University, Bikaner-334001, Rajasthan, India
}

Copyright (C) 2019 Jyotsna Begani et al. This is an open access article distributed under the terms of the Creative Commons AttributionNonCommercial-ShareAlike 4.0 International License which allows others to remix, tweak, and build upon the work non-commercially, as long as the author is credited and the new creations are licensed under the identical terms.

\begin{abstract}
The efficacy of an actinomycete strain JB66 recovered from a sand dune soil from the Bikaner district of the Thar desert in inhibiting the growth of various bacterial pathogens was studied. The type strains Staphylococcus aureus, Shigella flexneri, Klebsiella pneumoniae and the clinical isolates Escherichia coli, multidrug-resistant $S$. aureus and $P$. vulgaris were included in the antimicrobial assays. Polyphasic characterization of JB66 isolate revealed its identity as Streptomyces (MH762010). It showed 88.99-89.24\% sequence similarity with the other members of this genus and share the maximum (88.89\%) similarity with Streptomyces sp. ATSC13. The strain JB66 was found to produce a high amount of extracellular L-asparaginase, catalase, gelatinase, protease, tyrosinase and urease enzymes. The partial chemical categorization of the methanolic crude extract of the JB66 strain led to the preliminary identification of various metabolic compounds. The thin-layer chromatography fractionation revealed the presence of prodigiosin pigment or chandramycin, cephalosporin or zeatin, daidzein, demethoxy rapamycin, 4,6-dihydroxy-7methoxyisoflavone, munumbicins and amiclenomycin like compounds. Bio-autography revealed that the metabolites localized at the Rf values of $0.40,0.46$ and 0.53 in TLC profile had the actual bioactive fractions. UV-VIS spectrum absorbance maxima at $288 \mathrm{~nm}$ revealed the presence of an aromatic nucleus.
\end{abstract}

Keywords: Actinomycetes, Thar desert, Sand dune, MDR, TLC, Rapamycin, Cephalosporin.

DOI: 10.25004/IJPSDR.2019.110603

Int. J. Pharm. Sci. Drug Res. 2019; 11(6): 289-298

*Corresponding author: Dr. Dharmesh Harwani

Address: Department of Microbiology, Maharaja Ganga Singh University, Bikaner-334001, Rajasthan, India

Tel.: +91-8764131240

E-mail $\bowtie$ : dharmesh@mgsubikaner.ac.in

Relevant conflicts of interest/financial disclosures: The authors declare that the research was conducted in the absence of any commercial or

financial relationships that could be construed as a potential conflict of interest.

Received: 01 August, 2019; Revised: 30 October, 2019; Accepted: 12 November, 2019; Published: 30 November, 2019

\section{INTRODUCTION}

Nature is a prolific source of many useful natural products that play many prominent roles in the development of new therapeutic agents. ${ }^{[1-3]}$ A huge proportion of structurally different bioactive metabolites are synthesized by microorganisms to sustain in different ecosystems. [1, 4] Within microorganisms, actinobacteria represent the most promising group of bacteria that synthesize approximately two-thirds of all known natural bioactive products including some of the compounds most widely used as anticancer, anti-inflammatory, antibacterial, antifungal and antitumour agents etc. [5-16] Indeed, an estimated $70 \%$ or maybe more antibiotics 
currently used at the commercial levels are produced by the members of the genus Streptomyces in the phylum actinobacteria. ${ }^{[5,17-18]}$ Due to the emergence of multidrug-resistant pathogens against existing antibiotics, it is highly important to find the novel source of antibiotics and alternate methods on an urgent basis. By exploring the unexplored or less explored environment, the possibility of finding new biologically active metabolites can be increased. ${ }^{[19-21]}$ In this context, the less explored desert environment might be considered useful for finding novel actinobacterial bioactive metabolites. ${ }^{[22-26]}$ Therefore, in the present study, sampling was done from a sand dune soil in the Bikaner district of the Thar Desert for the isolation and identification of actinobacteria producing useful antibiotics against multidrugresistant pathogens. Intriguingly, based on the antagonistic activity against multidrug-resistant pathogens, a Streptomyces strain JB66 was identified producing cephalosporin and rapamycin like compounds.

\section{MATERIAL AND METHODS}

\section{Soil sampling and isolation of actinobacteria}

The samples were collected from a sand dune soil from the Bikaner region of the Thar desert in Rajasthan. The samples were collected at the depth of 6-10 $\mathrm{cm}$ using a sterile scoop in a sterile zipped bag. The collected samples were transferred to the laboratory for further analysis. To avoid the growth of undesired bacteria and for the selective isolation of actinomycetes, all samples were subjected to various pretreatment procedures before serial dilution. Pretreatment methods, drying [27${ }^{28]}$ and moist heating ${ }^{[29]}$ were employed. A pretreated soil sample was added to $50 \mathrm{~mL}$ of sterile distilled water in a $250 \mathrm{~mL}$ Erlenmeyer flask. This was kept for shaking on an orbital shaker for $30 \mathrm{~min}$ at $37^{\circ} \mathrm{C}$ and serial dilutions were made. From each dilution $0.1 \mathrm{~mL}$ of sample was spread on different selective isolation media namely ISP2 (International Streptomycete Project), [30] Benedict's modification of the Lindenbein [31], Czapek's [32], Gauze's [33], humic-acid vitamin [34-35] potassium-tellurite [36], raffinose-histidine [37], R2YE [38], starch-casein [39] and MAS [18] agar media. The antibiotics kanamycin, nalidixic acid and cyclohexamide $(25 \mu \mathrm{g} / \mathrm{ml})$ were added in the media to inhibit bacterial and fungal contaminations, respectively. The inoculated plates were incubated at $37^{\circ} \mathrm{C}$ for 7-20 days. Following incubation, the appearance and growth of microorganisms were observed every day. After isolation, the isolates were sub-cultured to ensure their purity and maintained on MAS agar medium and preserved using 20\% (v/v) glycerol at $-40^{\circ} \mathrm{C}$. [33]

\section{Screening for antibacterial activity}

The putative actinomycete isolates were screened for their antibacterial activity using the agar plug method [40] in primary screening. The type strains Staphylococcus aureus (NCIM 2079), Shigella flexneri (NCIM 4924) and
Klebsiella pneumoniae (NCIM 2719) and one clinical isolate Escherichia coli (clinical isolate responsible for Urinary Tract Infection (UTI) were used as the pathogens in antimicrobial assays. A fully grown culture of a pathogenic strain was seeded by swabbing on the MAS agar medium. After that, agar plugs were cut from 10 days old actinomycete agar culture and placed on the agar plate seeded with different pathogens in the separate experiments. The plates were incubated overnight at $37^{\circ} \mathrm{C}$ for $24-72 \mathrm{~h}$. Inhibition zones around the plugs after the incubation period were observed. The agar well diffusion method was used in the secondary screening to assess the antimicrobial activity of putative actinobacterial isolates. The isolates were grown in MAS broth medium. After centrifugation at 10,000 $\mathrm{g}$ for $10 \mathrm{~min}$, the culture supernatant was introduced in a well bored on the agar plate seeded with different pathogens. Consequently, the inhibitory zone produced was measured. During the time course of fermentation, antibiotic production, antimicrobial activity at different time points were also monitored. The isolate JB66 that exhibited broad-spectrum antimicrobial activity against the tested pathogens was selected for further studies.

Fermentation and biological activity of JB66 against MDR pathogens

The actinomycete isolate JB66 exhibiting the highest antagonistic activity against all the tested pathogen was cultured in ISP2 medium and incubated in a rotatory shaker at $120 \mathrm{rpm}$ at $30^{\circ} \mathrm{C}$ for 10 days. Subsequently, the culture broth was centrifuged (6000 g, $15 \mathrm{~min})$ and the supernatant was extracted with an equal volume of ethyl acetate (EA) at 1:1 (v/v) ratio. The extract was concentrated to dryness at $50^{\circ} \mathrm{C}$. Methanol was used to dissolve the crude extract and stored at $4^{\circ} \mathrm{C}$ until further use. The biological activity of the crude methanolic extract of actinobacterial isolate JB66 was tested against multidrug-resistant Gram-positive $S$. aureus and Gram-negative P. vulgaris (clinical isolates). Antibiotic-resistance profile of $S$. aureus was determined against amoxicillin-clavulanic acid $(30 \mu \mathrm{g})$, ampicillin $(10 \mu \mathrm{g})$, azithromycin $(30 \mu \mathrm{g})$, cefepime $(30 \mu \mathrm{g})$, ceftriaxone $(30 \mu \mathrm{g})$, cefotaxime $(30 \mu \mathrm{g})$, cefuroxime $(30 \mu \mathrm{g})$, cephalexin $(30 \mu \mathrm{g})$, ciprofloxacin

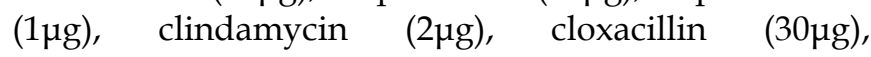
trimethoprim-sulfamethoxazole $(25 \mu \mathrm{g})$, erythromycin $(15 \mu \mathrm{g})$, imipenem $(10 \mu \mathrm{g})$, levofloxacin $(5 \mu \mathrm{g})$, linezolid $(30 \mu \mathrm{g}), \quad$ meropenem $(10 \mu \mathrm{g})$, piperacillin-tazobactam $(100 / 10 \mu \mathrm{g})$, teicoplanin $(30 \mu \mathrm{g})$, tetracycline $(30 \mu \mathrm{g})$, and vancomycin $(30 \mu \mathrm{g})$. Whereas antibiotic-resistance profile of $\mathrm{P}$. vulgaris was determined against amikacin $(30 \mu \mathrm{g})$, amoxicillin-clavulanic acid $(30 \mu \mathrm{g})$, aztreonam $(30 \mu \mathrm{g})$, cefepime $(30 \mu \mathrm{g}), \quad$ Cefoperazone-Sulbactam $(75 / 30 \mu \mathrm{g})$, ceftriaxone $(30 \mu \mathrm{g}), \quad$ cefotaxime $(30 \mu \mathrm{g})$, cefuroxime $(30 \mu \mathrm{g})$, ciprofloxacin $(1 \mu \mathrm{g})$, trimethoprimsulfamethoxazole $(25 \mu \mathrm{g})$, ertapenem $(10 \mu \mathrm{g})$, gatifloxacin $(5 \mu \mathrm{g})$, gentamicin $(10 \mu \mathrm{g})$, imipenem $(10 \mu \mathrm{g})$, levofloxacin $(5 \mu \mathrm{g})$, meropenem $(10 \mu \mathrm{g})$, netilmicin $(30 \mu \mathrm{g})$, norfloxacin $(10 \mu \mathrm{g})$, ofloxacin $(5 \mu \mathrm{g})$, piperacillin- 
tazobactam $(100 / 10 \mu \mathrm{g})$. The interpretation of their antibiotic susceptibilities was made using CLSI guidelines (M100-S22). [41]

\section{Scanning electron microscopy}

After the assessment of antimicrobial activity, the isolate JB66 that exhibited the highest anti-microbial activity against MDR pathogens was further subjected to its external morphological studies using scanning electron microscopy. The sample was prepared and analyzed according to the protocol described. [42]

\section{Phenotypic and biochemical characterization}

Morphological characterization of presumptive actinomycete isolate JB66 was performed by growing it on the ISP media as described by Shirling and Gottlieb (1966). ${ }^{[30]}$ The growth characteristics of 7 to 14 days old JB66 culture were determined using yeast extract/malt extract agar (ISP2), oatmeal agar (ISP3), inorganic salts/starch agar (ISP4), glycerol-asparagine agar (ISP5), peptone-yeast extract iron agar (ISP6) and tyrosine agar (ISP7) media and the colour of aerial and substrate mycelia was noted. The colonial morphology of the strain was examined by slide culture method. [33] Physiological characterization at variable $\mathrm{pH}$ range (511), temperature $\left(25-55^{\circ} \mathrm{C}\right)$ and salinity tolerance at different $\mathrm{NaCl}$ strength $(0-10 \%)$ was done. Briefly, in different assays, the isolate JB66 was inoculated into the broth tubes containing different salt concentrations and variable $\mathrm{pH}$ and incubated at $45^{\circ} \mathrm{C}$ for 7 days. The $\mathrm{pH}$ of the MAS broth medium was adjusted with $0.1 \mathrm{~N}$ $\mathrm{NaOH} / 0.1 \mathrm{~N} \mathrm{HCl}$. For temperature tolerance, the broth medium inoculated for JB66 strain was incubated at $25^{\circ} \mathrm{C}, 35^{\circ} \mathrm{C}, 45^{\circ} \mathrm{C}$ and $55^{\circ} \mathrm{C}$ separately. Carbohydrate utilization was determined by growing the isolate in ISP-9 medium [43] by using $1 \%$ of various carbon sources viz., arabinose, dextrose, fructose, galactose, Dglucose, lactose, mannitol, mannose, meso-inositol, pectin, rhamnose, ribose, salicin, sucrose, starch and Dxylose. The utilization of various nitrogen sources $(1 \%)$ was also studied by using alanine, aspartic acid, arginine, asparagine, cysteine, glutamic acid, glycine, histidine, isoleucine, methionine, proline, tyrosine, tryptophane in the basal medium consisted of $(\mathrm{g} / \mathrm{L})$ $\mathrm{K}_{2} \mathrm{HPO}_{4} 1.0 \mathrm{~g}, \mathrm{MgSO}_{4} .7 \mathrm{H}_{2} \mathrm{O} 0.5 \mathrm{~g}, \mathrm{CaCl}_{2} .2 \mathrm{H}_{2} \mathrm{O} 0.04 \mathrm{~g}$, $\mathrm{FeSO}_{2} .7 \mathrm{H}_{2} \mathrm{O} 0.005 \mathrm{~g}, \mathrm{ZnSO}_{4} .7 \mathrm{H}_{2} \mathrm{O} 0.0005 \mathrm{~g}$, $15 \mathrm{~g}$ agar and $1.0 \%$ of each of the nitrogen sources. The strain JB66 was screened for the production of extracellular catalase, amylase, cellulase, gelatinase, L-asparaginase, lipase, tyrosinase and urease enzymes.

\section{Molecular characterization}

Identification of the presumptive actinomycete isolate JB66 was performed by molecular taxonomy using $16 \mathrm{~S}$ rRNA gene sequence analysis. Genomic DNA was isolated as described previously. [38] The $16 \mathrm{~S}$ ribosomal DNA of JB66 isolate was amplified employing universal primers 27F5'AGAGTTTGATCCTGGCTCAG3' and 1525-R 5' AAGGAGGTGATCCAG CCGCA $3^{\prime}$ using a Thermocycler. ${ }^{[44-45]}$ The reaction was optimized with an initial denaturation at $95^{\circ} \mathrm{C}$ for $5 \mathrm{~min}$, followed by 30 cycles of DNA denaturation at $95^{\circ} \mathrm{C}$ for $1 \mathrm{~min}$, primerannealing at $44^{\circ} \mathrm{C}$ for $1 \mathrm{~min}$ and extension cycle at $72^{\circ} \mathrm{C}$ for $1.5 \mathrm{~min}$, with a final extension at $72^{\circ} \mathrm{C}$ for $10 \mathrm{~min}$. PCR-amplicon was visualized in $2 \%$ agarose gel electrophoresis and subsequently revealed with ethidium bromide staining. The amplified 16SrDNA gene product was sequenced using the Sanger didoxy method. Manual sequence edition, contig assembling and sequence alignment were executed using Vector NTI v10 software package. Sequencing results were analyzed for chimeras using DECIPHER v1.4.0 program. [46] The 16SrRNA gene sequences were compared with the GenBank/EMBL/DDBJ databases by using the BLASTN [47] search program. After pairwise alignment using CLUSTAL_X program v1.8 [48], the phylogenetic tree was constructed by using the neighbor-joining method [49] using MEGA X. ${ }^{[50]}$ Kimura 2-parameter method was used to compute the evolutionary distances of JB66 with other members of the genera. [51]

\section{Detection of polyketide synthases-II gene}

A set of degenerate primers (KSa 5'-TSG CST GCT TGG AYG CSA TC-3' and KS $\beta$ 5'-TGG AAN CCG CCG AAB CCT CT-3') for the specific amplification of the gene encoding polyketide synthases-II (PKS-II) in the strain JB66 was used. [52-53] The PCR reaction mixture contained $2.5 \mathrm{U}$ of Taq DNA polymerase, $1 \mathrm{mM} \mathrm{MgCl}_{2}$, $0.4 \mathrm{mM}$ deoxynucleoside triphosphates, 2 micromoles of each primer, and $5 \%$ dimethyl sulfoxide to a 50 microlitres volume. The actinobacterial DNA template was not added in the control reaction. The PCR reaction was optimized as one denaturation step of $94^{\circ} \mathrm{C}$ for 5 min, 30 amplification cycles of $94^{\circ} \mathrm{C}$ for $1 \mathrm{~min}$, primerannealing at $54^{\circ} \mathrm{C}$ for $1 \mathrm{~min}$, and extension cycle at $72^{\circ} \mathrm{C}$ for $2 \mathrm{~min}$ and a final extension at $72^{\circ} \mathrm{C}$ for $5 \mathrm{~min}$.

Chemical screening of crude extract by thin-layer chromatography and bioautography

The readymade pre-coated TLC plates (Merck; silica gel $60-\mathrm{F} 254 \mathrm{~nm}$ ) were used for the separation of the methanolic crude extract of the strain JB66. Using a capillary tube, a row of spots of the active fraction of the extract was applied $1 \mathrm{~cm}$ above the bottom of the TLC plate. The spots were then left to dry. The different solvent systems, including ethanol: water: chloroform (40:40:20), n-butanol: acetic acid: water (2:1:8), hexane: ethyl acetate (1:9), chloroform: methanol (18:2), dichloromethane: methanol (18:2), ethyl acetate: methanol (16:4), benzene: hexane (3:4) were initially used for the separation. Among different combinations, a mixture of chloroform: methanol (18:2) provided the best resolution and separation of chemical components from the JB66 methanolic extract. The TLC plate was placed vertically in a developing chamber containing the solvent chloroform: methanol in a ratio of 18:2, covered with the glass to prevent the evaporation. The solvent was allowed to migrate until it reaches $80 \%$ of the TLC plate. After that, the TLC plate was kept at room temperature for drying. After drying, the plate was viewed under UV (254 nm) and in iodine vapour. 
The Rf value of the spot separated on the TLC plate was determined by the following equation: [54]

\section{Distance traveled by the solute}

\section{$\mathbf{R f}=$ \\ Distance traveled by the solvent}

UV-visible absorption spectrum (200-600 nm) of the crude methanolic extract of JB66 was recorded on a spectrophotometer (Shimadzu) and bioautography was done using MDR pathogen $S$. typhi.

\section{RESULTS}

\section{Isolation of actinobacteria}

In the present study, many actinobacterial isolates were recovered from the samples collected from sand dune soil in the Bikaner district of the Thar desert in Rajasthan. Among various media tested, modified actinomycete selective (MAS) agar medium was found to be the best medium as it provided the highest yield of actinomycetes like colonies. An earthy smell, opaque, having a chalky appearance of fully grown colonies, strongly adhered to the agar medium, darker in the center, irregular, fuzzy edge, sometimes starshaped, hyphal appearance and leathery look, putative actinomycete like colonies were selected.

\section{Screening for antimicrobial activity}

Based on primary and secondary screening, the isolate JB66 exhibited the broad-spectrum antimicrobial activity against the tested bacterial pathogens. The strain JB66 showed antimicrobial activity with the inhibition zones (measured in diameter) of $21 \mathrm{~mm}$ against Shigella flexneri, $20 \mathrm{~mm}$ against E coli, $27 \mathrm{~mm}$ against Staphylococcus aureus and $20 \mathrm{~mm}$ against Klebsiella pneumoniae. Biological extracts (supernatant) collected from the JB66 strain exhibited the maximum growth inhibition of the pathogens tested in the present study after eight days of incubation and then declined (Figure 1).

Biological activity of JB66 against MDR pathogens

Two clinical isolates $P$. vulgaris and $S$. aureus were tested against various antibiotics (Hi-Media, Mumbai) to determine their antibiogram profile (Table 1). Among the selected 20 antibiotics, P. vulgaris was found to be resistant $(R)$ against 13 tested antibiotics namely amoxicillin-clavulanic acid $(30 \mu \mathrm{g})$, aztreonam $(30 \mu \mathrm{g})$, ceftriaxone $(30 \mu \mathrm{g})$, cefotaxime $(30 \mu \mathrm{g})$, cefuroxime $(30 \mu \mathrm{g})$, ertapenem $(10 \mu \mathrm{g})$, gatifloxacin $(5 \mu \mathrm{g})$, gentamicin $(10 \mu \mathrm{g})$, meropenem $(10 \mu \mathrm{g})$, netilmicin $(30 \mu \mathrm{g})$, norfloxacin $(10 \mu \mathrm{g})$, ofloxacin $(5 \mu \mathrm{g})$, piperacillintazobactam $(100 / 10 \mu g)$ antibiotics (Figure 2) and

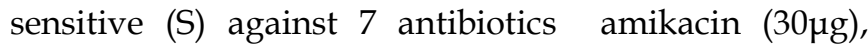
cefepime $(30 \mu \mathrm{g})$, cefoperazone-sulbactam $(75 \mu \mathrm{g}-30 \mu \mathrm{g})$, ciprofloxacin (1 $\mu \mathrm{g})$, trimethoprim-sulfamethoxazole $(25 \mu \mathrm{g})$, imipenem $(10 \mu \mathrm{g})$, levofloxacin $(5 \mu \mathrm{g})$ with the zone of inhibition (in mm) 20, 20, 17.5, 20, 17, 23,19 respectively (Table 1 ). On the other hand, among 21 tested antibiotics, S. aureus was found to be resistant (R) against 16 antibiotics namely amoxicillin-clavulanic acid $(30 \mu \mathrm{g})$, ampicillin $(10 \mu \mathrm{g})$, azithromycin $(30 \mu \mathrm{g})$, cefepime $(30 \mu \mathrm{g})$, ceftriaxone $(30 \mu \mathrm{g})$, cefotaxime $(30 \mu \mathrm{g})$, cephalexin $\quad(30 \mu \mathrm{g}), \quad$ cloxacillin $\quad(30 \mu \mathrm{g})$, trimethoprim/sulfamethoxazole $(25 \mu \mathrm{g})$, erythromycin

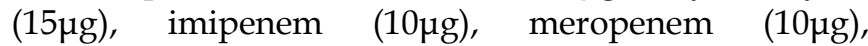
piperacillin-tazobactam $(100-10 \mu g)$, teicoplanin $(30 \mu \mathrm{g})$, tetracycline $(30 \mu \mathrm{g})$, and vancomycin $(30 \mu \mathrm{g})$ antibiotics. While it was found sensitive against 5 antibiotics namely cefuroxime $(30 \mu \mathrm{g})$, ciprofloxacin (1 $\mathrm{gg})$, clindamycin $(2 \mu \mathrm{g})$, levofloxacin $(5 \mu \mathrm{g})$, linezolid $(30 \mu \mathrm{g})$ with zone of inhibition (in $\mathrm{mm}$ ) 18, 21, 22, 20, 23 respectively (Table 1) (Figure 2). The methanolic extract of the isolate JB66 exhibited the growth inhibitory effect against both MDR pathogens by producing an inhibition zone diameter of $22 \mathrm{~mm}$ against MDR $S$. aureus and $19 \mathrm{~mm}$ against MDR $P$. vulgaris (Table 1 ) (Figure 3).

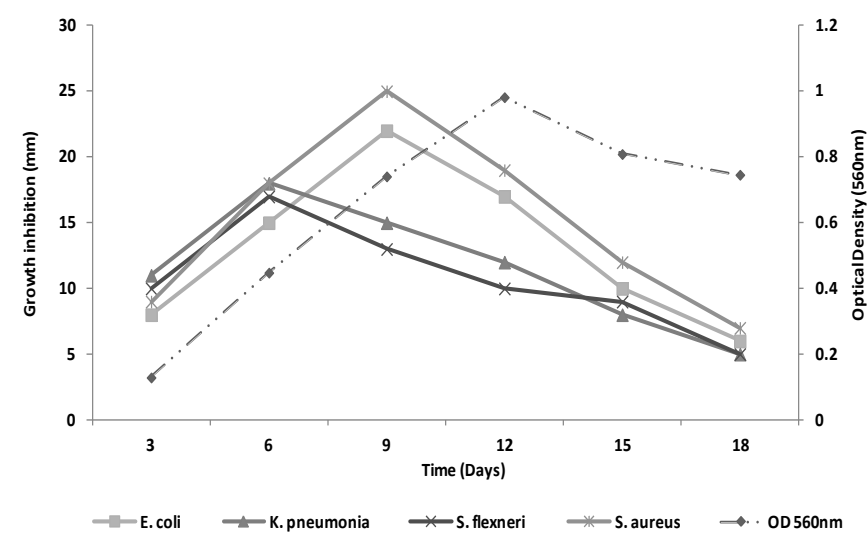

Fig. 1: Analyses of antimicrobial product formation, optical growth density and growth inhibition by JB66 strain against $E$. coli, $K$. pneumoniae, S. flexneri and S. aureus.

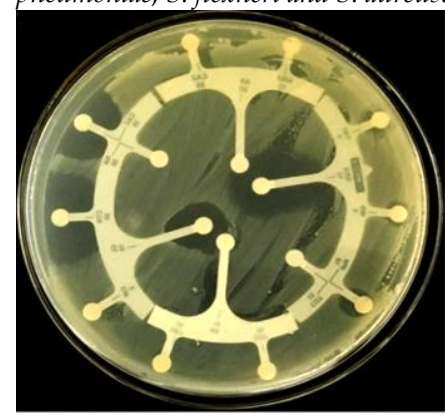

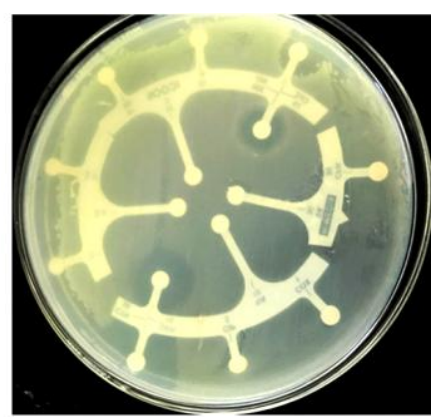

Fig. 2: Antibiotic susceptibility of MDR pathogens (i) $S$. and (ii) Proteus vulgaris. The antibiogram profile of pathogens was prepared using Icosa discs on a $200 \mathrm{~mm}$ plate. Both the pathogens were found resistant for most the antibiotics tested

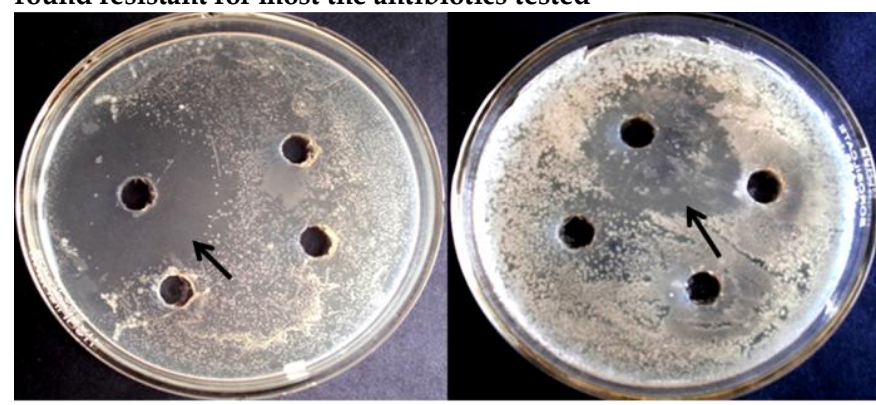

A

B

Fig. 3: Antimicrobial activities of the methanolic crude extract from JB66 against multidrug-resistant (A) S. aureus (B) Proteus Vulgaris. JB66 strain exhibited the maximum growth inhibition against $S$. aureus measured as a diameter of inhibition zone $(\mathrm{mm})$ 
Table 1: Antibacterial activity of JB66 against MDR clinical isolates and their antibiotic susceptibility

\begin{tabular}{|c|c|c|}
\hline \multirow{2}{*}{ Treatment } & \multicolumn{2}{|c|}{ Zone of inhibition (mm) } \\
\hline & P. vulgaris $\#$ & S. aureus ${ }^{\#}$ \\
\hline JB66 & 19 & 22 \\
\hline Amikacin $(30 \mu \mathrm{g})$ & $20(S)$ & nt \\
\hline Amoxicillin-clavulanic acid $(30 \mu \mathrm{g})$ & $8(\mathrm{R})$ & $10(\mathrm{R})$ \\
\hline Aztreonam $(30 \mu \mathrm{g})$ & $0(\mathrm{R})$ & nt \\
\hline 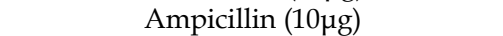 & nt & (R) \\
\hline Azithromycin $(30 \mu \mathrm{g})$ & nt & $7(\mathrm{R})$ \\
\hline Cefepime $(30 \mu \mathrm{g})$ & $20(S)$ & $0(\mathrm{R})$ \\
\hline 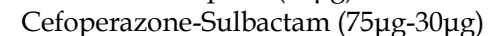 & $17.5(S)$ & nt \\
\hline Ceftriaxone $(30 \mu \mathrm{g})$ & $11(\mathrm{R})$ & $8(\mathrm{R})$ \\
\hline Cefotaxime $(30 \mu \mathrm{g})$ & $6(\mathrm{R})$ & $0(\mathrm{R})$ \\
\hline Cefuroxime $(30 \mu \mathrm{g})$ & $9(\mathrm{R})$ & $18(\mathrm{~S})$ \\
\hline Cephalexin $(30 \mu \mathrm{g})$ & $\mathrm{nt}$ & $5(\mathrm{R})$ \\
\hline Ciprofloxacin (1 $1 \mu \mathrm{g})$ & $20(\mathrm{~S})$ & $21(S)$ \\
\hline Clindamycin $(2 \mu \mathrm{g})$ & nt & $22(S)$ \\
\hline Cloxacillin $(30 \mu \mathrm{g})$ & nt & $0(\mathrm{R})$ \\
\hline Trimethoprim-sulfamethoxazole $(25 \mu \mathrm{g})$ & $17(\mathrm{~S})$ & 9(R) \\
\hline Ertapenem $(10 \mu \mathrm{g})$ & $0(\mathrm{R})$ & $\mathrm{nt}$ \\
\hline Erythromycin $(15 \mu \mathrm{g})$ & nt & $6(\mathrm{R})$ \\
\hline Gatifloxacin $(5 \mu \mathrm{g})$ & 12(R) & nt \\
\hline Gentamicin $(10 \mu \mathrm{g})$ & $8(\mathrm{R})$ & $\mathrm{nt}$ \\
\hline Imipenem (10ug) & $23(S)$ & 6(R) \\
\hline Levofloxacin $(5 \mu \mathrm{g})$ & 19(S) & $20(S)$ \\
\hline 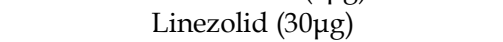 & nt & 23(S) \\
\hline Meropenem $(10 \mu \mathrm{g})$ & $9(\mathrm{R})$ & $7(\mathrm{R})$ \\
\hline 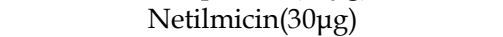 & $0(\mathrm{R})$ & $\mathrm{nt}$ \\
\hline Norfloxacin $(10 \mu \mathrm{g})$ & $7(\mathrm{R})$ & nt \\
\hline Ofloxacin (5ug) & 6(R) & nt \\
\hline Piperacillin-tazobactam(100-10 $\mu \mathrm{g})$ & $10(\mathrm{R})$ & $8(\mathrm{R})$ \\
\hline Teicoplanin $(30 \mu \mathrm{g})$ & nt & $5(\mathrm{R})$ \\
\hline Tetracycline $(30 \mu \mathrm{g})$ & nt & 9(R) \\
\hline Vancomycin $(30 \mu \mathrm{g})$ & nt & $5(\mathrm{R})$ \\
\hline
\end{tabular}

\#, Clinical isolates; (R), Resistant; (S), Sensitive; nt, not tested; interpretation based on CLSI guidelines (M100-S22).

Table 2: Morphological and cultural characteristics of JB66 on different ISP media

\begin{tabular}{|c|c|c|c|c|c|c|c|c|}
\hline \multirow[b]{2}{*}{$\begin{array}{l}\text { Isol } \\
\text { ate }\end{array}$} & \multirow{2}{*}{$\begin{array}{l}\text { Aerial } \\
\text { (AM) } \\
\text { and } \\
\text { substrate } \\
\text { myceliu } \\
\text { m (SM) }\end{array}$} & \multicolumn{7}{|c|}{ ISP media } \\
\hline & & $\vec{\omega}$ & $\begin{array}{l}N \\
\hat{\omega}\end{array}$ & $\stackrel{m}{\omega}$ & $\stackrel{\pi}{\omega}$ & $\begin{array}{l}10 \\
\hat{\omega} \\
\end{array}$ & $\begin{array}{l}0 \\
\stackrel{n}{n}\end{array}$ & $\hat{\bar{n}}$ \\
\hline & $\mathrm{AM}$ & $\begin{array}{l}\text { Whitis } \\
\text { h grey }\end{array}$ & $\begin{array}{l}\text { Light } \\
\text { grey }\end{array}$ & $\begin{array}{c}\text { Lig } \\
\text { ht } \\
\text { grey }\end{array}$ & Grey & Grey & $\begin{array}{l}\text { Light } \\
\text { Grey }\end{array}$ & $\begin{array}{l}\text { Light } \\
\text { grey }\end{array}$ \\
\hline JB66 & SM & $\begin{array}{c}\text { Yellow } \\
\text { ish } \\
\text { White }\end{array}$ & $\begin{array}{c}\text { Pale } \\
\text { whit } \\
\text { e }\end{array}$ & $\begin{array}{c}\text { Pale } \\
\text { whi } \\
\text { te }\end{array}$ & $\begin{array}{c}\text { Light } \\
\text { brow } \\
\mathrm{n}\end{array}$ & $\begin{array}{c}\text { Yello } \\
\text { wish } \\
\text { Whit } \\
\text { e }\end{array}$ & $\begin{array}{c}\text { Grey } \\
\text { Whit } \\
\text { e }\end{array}$ & $\begin{array}{c}\text { Light } \\
\text { brow } \\
n\end{array}$ \\
\hline
\end{tabular}

\section{Morphological and physiological characteristics of} JB66

The Gram-positive actinobacterial isolate JB66 showed typical mycelial structure in Gram's staining (Figure 4). The scanning electron micrograph of the isolate JB66 revealed a cubic form, smooth spore chain (Figure 4). It exhibited white-gray aerial mycelium and yellowishwhite substrate mycelium on tryptone-yeast extract (ISP-1) agar, light gray aerial mycelium and pale white substrate mycelium on yeast extract-malt extractdextrose (ISP-2) agar, light gray color aerial mycelium and pale white substrate mycelium on oat-meal agar (ISP-3), grey aerial mycelium and light brown substrate mycelium starch-inorganic salts (ISP-4) agar and grey aerial and yellowish white substrate mycelium on glycerol-asparagine (ISP-5) agar. The growth of JB66 was observed to be moderate on ISP6, exhibiting light grey aerial mycelium and grey white substrate mycelium whereas on tyrosine agar (ISP-7), it also showed moderate growth with light grey aerial and light brown substrate mycelium (Figure 5) (Table 2).

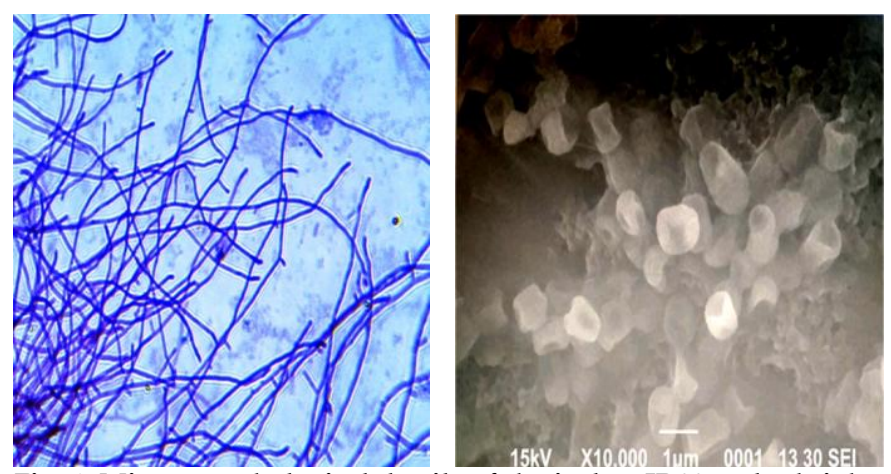

Fig. 4: Micro-morphological details of the isolate JB66 under bright field microscope (Left: Photomicrograph of mycelia) and scanning electron micrograph of spores (right)

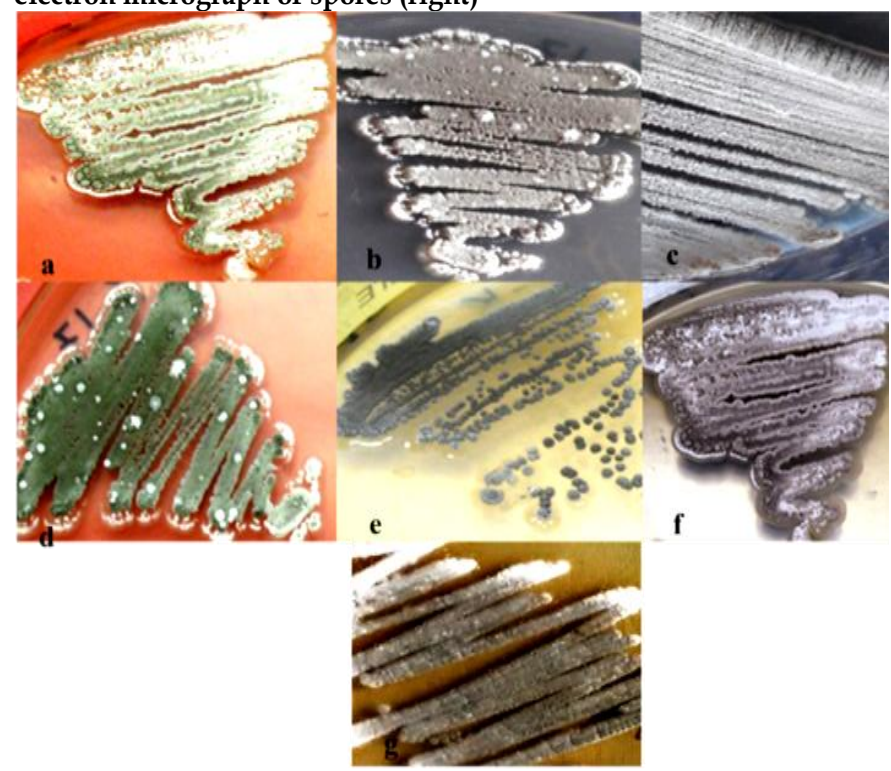

Fig. 5: Phenotypic appearance of JB66 strain on various ISP Media (a) tryptone yeast extract agar (ISP1), (b) yeast extract maltose agar (ISP2), (c) oatmeal agar (ISP3), (d) inorganic salt starch agar (ISP4), (e) glycerol asparagine agar (ISP5), (f) peptone yeast extract iron agar (ISP6), (g) tyrosine agar (ISP7)

The details of the physiological and biochemical characteristics of the isolate JB66 have been furnished in Table 3. The isolate JB66 efficiently utilized galactose, D-xylose, sucrose, rhamnose, fructose, dextrose, lactose, salicin, meso-inositol, ribose, mannose, pectin, starch, D-glucose, arabinose and mannitol (Table 3). It efficiently utilized various nitrogen sources namely glycine, histidine, aspartic acid, proline, tyrosine, isoleucine, cysteine, tryptophane, arginine, asparagine except alanine, methionine and glutamic acid. The growth of the isolate was observed in the $\mathrm{pH}$ range of 5-11 with growth optima at $\mathrm{pH} 7$. The temperature tolerance range was observed to be $25-45^{\circ} \mathrm{C}$ with the optimum temperature being $35^{\circ} \mathrm{C}$. Similarly, the isolate JB66 tolerated salt concentration up to $7.5 \%(\mathrm{w} / \mathrm{v})$. JB66 was observed to be a good producer of extracellular enzymes amylase, L-asparaginase, protease and a 
moderate producer of cellulase, tyrosinase and urease enzymes while it was not observed to produce extracellular enzyme lipase. It showed positive activity for the catalase and gelatinase enzymes and the negative activity for DNAse enzyme.

Table 3: Biochemical and physiological characteristics

\begin{tabular}{|c|c|c|}
\hline Parameter & Variables & Growth \\
\hline \multirow{18}{*}{ Carbon Sources } & Arabinose & + \\
\hline & D-Mannitol & + \\
\hline & Galactose & + \\
\hline & D-Xylose & + \\
\hline & Sucrose & + \\
\hline & Rhamnose & + \\
\hline & Fructose & + \\
\hline & Dextrose & + \\
\hline & Lactose & + \\
\hline & Salicin & + \\
\hline & Meso-inositol & + \\
\hline & Ribose & + \\
\hline & Mannose & + \\
\hline & Pectin & + \\
\hline & D-Glucose & + \\
\hline & Alanine & - \\
\hline & Glycine & + \\
\hline & Histidine & + \\
\hline \multirow[t]{12}{*}{ Nitrogen Sources } & Methionine & - \\
\hline & Glutamic acid & - \\
\hline & Aspartic acid & + \\
\hline & Proline & + \\
\hline & Tyrosine & + \\
\hline & Isoleucine & + \\
\hline & Cysteine & + \\
\hline & Tryptophane & + \\
\hline & Arginine & + \\
\hline & Aspargine & + \\
\hline & 5 & - \\
\hline & 7 & + \\
\hline \multirow{3}{*}{$\mathrm{pH}$} & 9 & - \\
\hline & 11 & - \\
\hline & 25 & + \\
\hline \multirow{5}{*}{ Temperature $\left({ }^{\circ} \mathrm{C}\right)$} & 37 & + \\
\hline & 45 & + \\
\hline & 55 & - \\
\hline & 0 & + \\
\hline & 1 & + \\
\hline \multirow{9}{*}{$\mathrm{NaCl}(\%)$} & 2.5 & + \\
\hline & 5 & + \\
\hline & 7.5 & + \\
\hline & 10 & - \\
\hline & Amylase & + \\
\hline & Catalase & + \\
\hline & Cellulase & + \\
\hline & DNAse & - \\
\hline & Gelatinase & + \\
\hline \multirow[t]{6}{*}{ Extracellular enzyme } & L-asparginase & + \\
\hline & Lipase & - \\
\hline & Protease & + \\
\hline & Phosphatase & - \\
\hline & Tyrosinase & + \\
\hline & Urease & + \\
\hline
\end{tabular}

+ good growth, - poor growth

\section{Molecular characterization}

The 16SrDNA sequence of the strain JB66 after Sanger sequencing was submitted to the GenBank database under an accession number MH762010. The query sequence was aligned and compared with the available 16SrDNA gene sequences in the GenBank database by using multi-sequence advanced BLAST comparison. It revealed that the isolate JB66 belongs to the genus Streptomyces. It showed 88.99-89.24\% sequence similarity with its members and share the maximum $(88.89 \%)$ similarity to Streptomyces sp. ATSC13. The phylogenetic analysis indicated that JB66 is clustered singly in the phylogenetic tree with the nearest neighbor exhibiting a similarity score of $<97 \%(88.89 \%)$ suggesting the strain might belong to a possible new species (Figure 6).

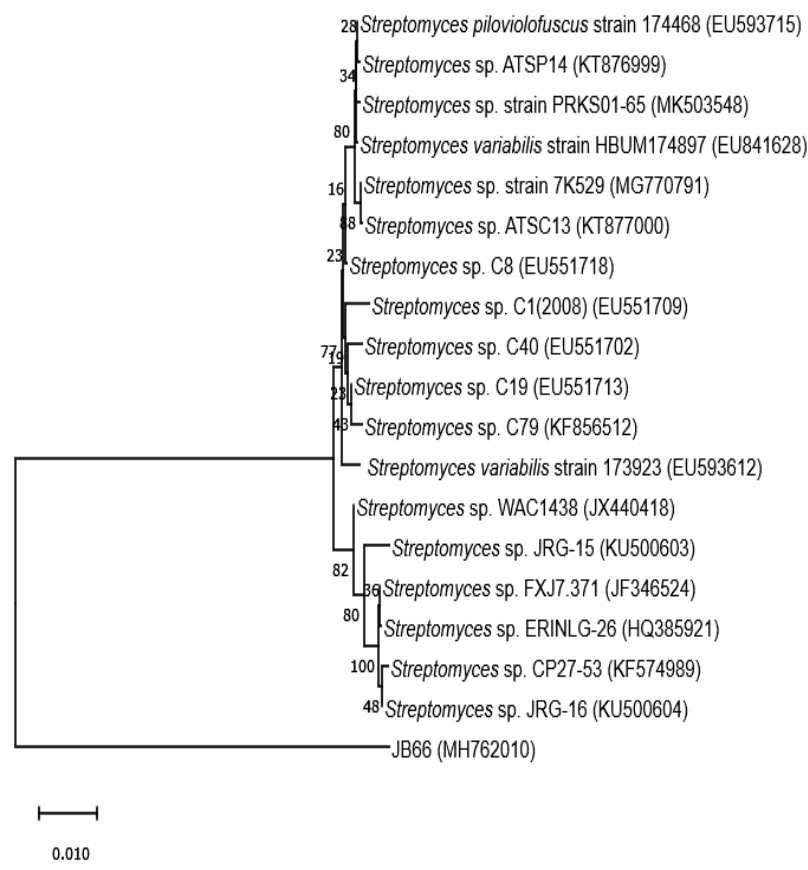

Fig. 6: The evolutionary relationship of JB66 was inferred using the Neighbor-Joining method. The \% of replicate trees for the associated taxa (clustered for the bootstrap test) is shown next to the branches. The tree is drawn to scale. Kimura 2-parameter method was used to compute the evolutionary distances (number of base substitutions per site). Among sites, the rate variation was modeled with a gamma distribution (shape parameter $=2$ ). Evolutionary analyses were conducted in MEGA $X$

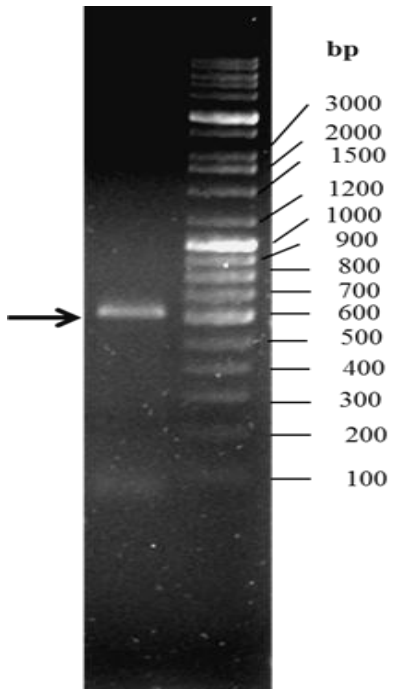

Fig. 7: PCR amplification of PKS type II biosynthetic gene. An amplicon size of $\sim 600 \mathrm{bp}$, denoted by an arrow, for PKS-II gene, confirmed its presence in the actinomycete strain JB66

\section{Detection of PKS-II gene}

To evaluate the biosynthetic potential, the strain JB66 was screened for the presence of PKS-II gene sequence by specific amplification of its chromosomal DNA. 
Amplicon size of $\sim 600 \mathrm{bp}$ for PKS type II confirmed the presence of this biosynthetic gene in the actinobacterial strain JB66 (Figure 7).

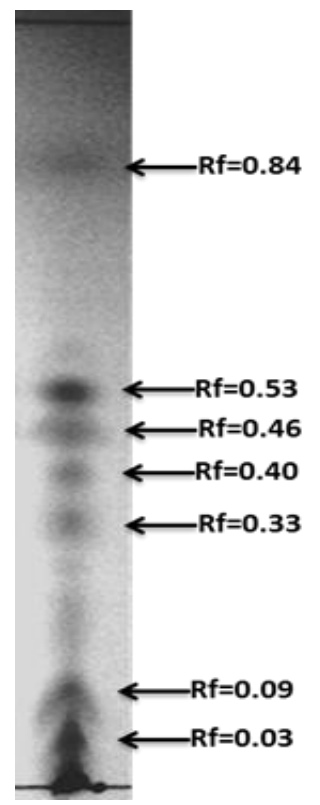

Fig. 8: Thin layer chromatograph showing the bio-active compound extracted from the fermentation broth of the JB66 strain. TLC was visualized under UV light and iodine spray

\subsection{0}

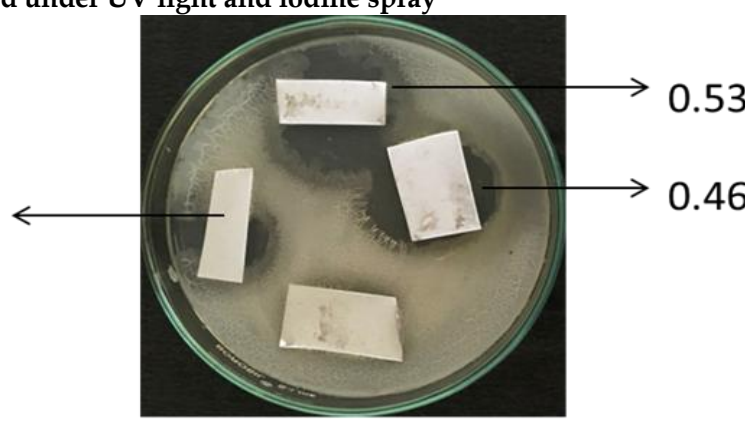

Fig. 9: Bio-autography to assess the activity of various compounds produced by JB66 TLC. Rf values of 0.53 (possible cephalosporin like aromatic or polyene compound), 0.40 (possible demethoxy rapamycin like compound), 0.46 (possible daidzein like compound) fractionated compounds exhibited the strong inhibitory activity against $S$. typhi

\section{Thin-layer chromatography and bio-autography}

The separation of the metabolic compounds present in the methanolic extract of the strain JB66 was done using TLC. Among various solvent systems in various proportions, chloroform: methanol in 18:2 proportions showed a good separation. The Rf values of TLC fractionated compounds were calculated to be 0.83 , $0.53,0.46,0.40,0.33,0.09,0.03$ (Figure 8). The Rf values of the separated spots on silica gel TLC led to the preliminary identification of prodigiosin pigment or chandramycin ( $\mathrm{Rf} 0.84$ ), cephalosporin or zeatin ( $\mathrm{Rf}$ $0.53)$, daidzein ( $\operatorname{Rf} 0.46)$, demethoxy rapamycin ( $R f$ 0.40), 4,6-dihydroxy-7-methoxyisoflavone ( $\mathrm{Rf} 0.33$ ), munumbicins (Rf 0.09) and amiclenomycin (0.03) like compounds (Table 4). The bioautography of metabolites, fractionated on the TLC plate at different $\mathrm{Rf}$ values revealed that the fractions with $\mathrm{Rf}$ value of $0.40,0.46,0.53$ value were actually associated with the antimicrobial activity. The inhibition zone around the excised TLC fraction (band/spot) showed the bioactive part against $S$. typhi (Figure 9). The JB66 extract showed UV-VIS spectrum absorbance maxima at $288 \mathrm{~nm}$ that indicated the presence of an aromatic nucleus.

Table 4: Putative compounds and their structures identified in the TLC profile of JB66

\begin{tabular}{|c|c|c|}
\hline Rf & Name of compound & Structure of compound \\
\hline 0.84 & Prodigiosin-like pigments & \\
\hline 0.53 & $\begin{array}{l}\text { Cephalosporin like } \\
\text { aromatic or polyene } \\
\text { compound }\end{array}$ & \\
\hline 0.46 & Daidzein like compound & \\
\hline 0.40 & Demethoxy Rapamycin & \\
\hline 0.33 & $\begin{array}{l}\text { 4',6-Dihydroxy-7- } \\
\text { methoxyisoflavone }\end{array}$ & \\
\hline 0.03 & Amiclenomycin & \\
\hline
\end{tabular}

\section{DISCUSSION}

The genus Streptomyces has gained global attention due to its ability to produce many useful biologically active metabolites. The most common source to isolate Streptomyces is soil; nevertheless, the rate of discovery of novel metabolites from broadly explored terrestrial strains has considerably diminished. [55] The probability of discovering novel metabolites could be increased by exploring the unexplored or less explored environments. Consequently, the bioprospecting of Streptomyces derived secondary metabolites from the less explored ecological niches has been recommended. [56-57] Therefore, an attempt was made in the present study to explore the unexplored Bikaner district of the Thar desert in Rajasthan to isolate actinomycetes producing therapeutically important metabolites. Although a few reports exist on the prevalence of actinomycetes in the desert ecosystems [11, 25, 58-63], to date, there has been no such a detailed study conducted to address the antimicrobial potential of these actinobacteria against multidrug-resistant pathogens. Among various isolates, recovered from the samples of sand dune soil, the isolate JB66 exhibited the broad- 
spectrum antibacterial activity against the bacterial pathogens including MDR pathogens. Based on the phenotypic and molecular characteristics of the isolate JB66, it was identified as a member of the genus Streptomyces. [64] 16SrRNA gene sequence analysis revealed that it has the closest sequence similarity $(\sim 89 \%)$ with Streptomyces sp. (KT877000.1). The colour of the aerial and substrate mycelia of actinomycetes has been observed to be medium-dependant ${ }^{[65]}$ and serves as one of the important colonial characteristics for taxonomical studies. ${ }^{[66-67]}$ The isolates with abundant powdery spores and with an earthy odor of geosmin are usually classified as streptomycete-like strains. [68] Similarly, the actinomycete isolate JB66 grew well on the different ISP media used that further confirmed its identity as a member of the genus Streptomyces. The methanolic crude extract of the strain JB66 showed significant antimicrobial activity against MDR $P$. vulgaris and $S$. aureus. In a previous study, the in vitro potential of the bioactive crude extracts of five putative novel species of actinobacteria was assessed. These isolates were recovered from the Indian Thar desert that exhibited antibacterial activity against multidrugresistant (MDR) Streptococcus pneumonia. [25] Saadoun and Gharaibehalso reported antibacterial activity of sixty different Streptomyces isolates from Badia Region of Jordan desert against B. subtilis, S. aureus, E. coli, Klebsiella sp. and Shigella sp. ${ }^{[69]}$ The Selvameenal group also reported a yellow pigment producing Streptomyces from the Thar desert soil that exhibits antibiotic activity against methicillin-resistant Staphylococcus aureus (MRSA), vancomycin-resistant Staphylococcus aureus (VRSA) and extended-spectrum $\beta$-lactamases (ESBL) cultures of E. coli and Klebsiella, [62]

Thin-layer chromatography was used in the present study for the fractionation of crude methanolic extracts of the strain JB66. Among many of the solvent systems tested, chloroform: methanol (18:2) was found to be the most effective solvent system that provided the best separation. The different $\mathrm{Rf}$ values of the separated spots observed on the silica gel plate (TLC) led to the preliminary identification of various chemical compounds. The fraction with Rf value of 0.84 exhibited the presence of chandramycin like compound, previously this novel antibiotic was extracted with organic solvents from the culture broth of Streptomyces lydicus, a plant pathogenic actinomycete (isolated from deep-pitted scab lesions of potato tubers). ${ }^{70]}$ The $\mathrm{Rf}$ value of 0.84 exhibited the presence of prodigiosin like compound, a red pigment produced by Serratia, Pseudomonas, Streptomyces and Vibrio spp. This pigment has been reported to have antibacterial, antifungal, antimalarial and antineoplastic activity. ${ }^{[71]}$ The fraction with $\mathrm{Rf}$ value of 0.53 exhibited the presence of cephalosporin (0.527) like compound that has been reported to be produced by Streptomyceshalstedii-olivaceus AA32 and AA33. [72]
Similarly, the fraction with Rf value of 0.40 exhibited the presence of demethoxy rapamycin like compound, earlier reported to be produced by Streptomyces hygroscopicus that posses a broad spectrum antagonistic activity against few Gram-positive and Gram-negative bacteria and fungi. [73] Rapamycin is a macrocyclic natural product that exhibits various biological and pharmacological activities, including antifungal, immunosuppressive, antitumor, neuroprotective, and anti-aging activities. The fraction at $\mathrm{Rf}$ values of 0.46 and 0.33 exhibited the presence of isoflavanoids daidzein and 4,6-dihydroxy-7-methoxyisoflavone (Kakkatin) like compounds respectively. These are plant flavonoids that have been identified after chromatographic separation in Streptomyces sp. GW10/1811 and Streptomyces sp. GW39/1530. [74] The fraction with Rf value of 0.03 exhibited the presence of amiclenomycin like compound, which was observed to be produced by the culture filtrates of a Streptomyces lavendulae subsp. amiclenomycini (Streptomyces strain MD580-S1). The compound amiclenomycin has been reported to inhibit the growth of mycobacteria, including antibiotic-resistant mycobacteria. [75] The fraction with $\mathrm{Rf}$ value of 0.09 exhibited the presence of munumbicins like compound which was previously reported in Streptomyces NRRL 3052. The strain was isolated from medicinal plant snakevine (Kennedia nigriscans), native to the Northern Territory of Australia. This compound has been known to exhibit broad-spectrum activity against many human and plant pathogenic fungi, bacteria and Plasmodium sp. ${ }^{[7]}$ In the present study, after the fractionation of crude extracts in TLC, the actual bioactive fractions were recognized using bio-autography. A total of three fractions of chemical compounds with Rf values of 0.40 , $0.46,0.53$ of JB66 methanolic extract were observed to be bioactive against MDR pathogen. To confirm this further, putatively identified chemical compounds will be confirmed in LC-MS analysis. In conclusion, it can be stated that the metabolic compounds from the strain JB66 can serve as potential candidates for the development of chemotherapeutic drugs to control the infections caused by MDR pathogens in the future.

\section{REFERENCES}

1. Burja AM, Banaigs B, Abou-Mansour E, Burgess JG, Wright PC. Marine cyanobacteria-a prolific source of natural products. Tetrahedron. 2001; 57:9347-9377.

2. Karikas G. Anticancer and chemopreventing natural products: some biochemical and therapeutic aspects. J Buon. 2010; 15:627-638.

3. Newman DJ, Cragg GM. Natural Products as Sources of New Drugs from 1981 to 2014. J Nat Prod. 2016; 79(3):629-661.

4. Chin YW, Balunas MJ, Chai HB, Kinghorn AD. Drug discovery from natural sources. The AAPS journal. 2006; 8:E239-E253.

5. Berdy J. Bioactive microbial metabolites. J Antibiot. 2005; 58:1-26.

6. Schumacher RW, Talmage SC, Miller SA, Sarris KE, Davidson BS, Goldberg A. Isolation and structure 
determination of an antimicrobial ester from a marine sediment derived bacterium. J Nat Prod. 2003; 66:1291-1293.

7. Soria-Mercado IE, Prieto-Davo A, Jensen PR, Fenical W. Antibiotic terpenoid chloro-dihydroquinones from a new marine actinomycete. J Nat Prod. 2005; 68:904-910.

8. Williams PG, Miller ED, Asolkar RN, Jensen PR, Fenical W. Arenicolides A-C 26-membered ring macrolides from the marine actinomycete Salinispora arenicola. J Org Chem. 2007; 72:5025-5034

9. Caffrey P, Aparicio JF, Malpartida F, Zotchev SB Biosynthetic engineering of polyene macrolides towards generation of improved antifungal and antiparasitic agents. Curr Top Med Chem. 2008; 8:639-653.

10. Demain AL, Sanchez S. Microbial drug discovery: 80 years of progress. J Antibiot. 2009; 62: 5-16.

11. Nachtigall J, Kulik A, Helaly S, Bull AT, Goodfellow M, Asenjo JA, Maier A, Wiese J, Imhoff JF, Sussmuth RD, Fiedler HP. Atacamycins A-C, 22-membered antitumor macrolactones produced by Streptomyces sp. C38. J Antibiot. 2011; 64(12):775-780.

12. Lu J, Ma Y, Liang J, Xing Y, Xi T, Lu Y. Aureolic acids from a marine-derived Streptomyces sp. WBF16. Microbiol Res. 2012; 167:590-595.

13. Liu DZ, Liang BW. A new pyrrolosesquiterpene isolated from cultures of Streptomyces sp. J Antibiot (Tokyo). 2014; 67:415-417.

14. Wan Z, Fang W, Shi L, Wang $K$, Zhang $Y$, Zhang Z, Wu Z, Yang Z, Gu Y. Novonestmycins A and B, two new 32membered bioactive macrolides from Streptomyces phytohabitans HBERC-20821. J Antibiot (Tokyo). 2015; 68:185190.

15. Jiao J, Paterson J, Busche T, Rückert C, Kalinowski J, Harwani $\mathrm{D}$, Gross H. Draft genome sequence of Streptomyces sp. strain DH-12, a soilborne isolate from the Thar Desert with broadspectrum antibacterial activity. Genome Announc. 2018; 6(9):1-3.

16. Begani J, Lakhani J, Harwani D. Current strategies to induce secondary metabolites from microbial biosynthetic cryptic gene clusters. Ann Microbiol. 2018; 68:419-432.

17. Watve MG, Tickoo R, Jog MM, Bhole BD. How many antibiotics are produced by the genus Streptomyces? Arch Microbiol. 2001; 176:386-390.

18. Begani J, Lakhani J, Harwani D. A broad-spectrum antimicrobial activity of thermophilic Nocardiopsis sp. producing multiple extracellular enzymes of industrial and therapeutic use. Asian J Pharm Pharmacol. 2019; 5:525-534.

19. Clardy J, Fischbach MA, Currie CR. The natural history of antibiotics. Curr Biol. 2009; 19:R437-R441.

20. Guo X, Liu N, Li X, Ding Y, Shang F, Gao Y, Ruan J and Huang Y. Red soils harbor diverse culturable actinomycetes that are promising sources of novel secondary metabolites. Appl Environ Microbiol. 2015; 81:3086-3103.

21. Sengupta S, Pramanik A, Ghosh A, Bhattacharyya M. Antimicrobial activities of actinomycetes isolated from unexplored regions of Sundarbans mangrove ecosystem. BMC Microbiology. 2015; 15:170-185.

22. Goodfellow M, Fiedler HP. A guide to successful bioprospecting: informed by actinobacterial systematics. Antonie Van Leeuwenhoek. 2010; 98:119-142.

23. Mao J, Wang J, Dai HQ, Zhang ZD, Tang QY, Ren B, Yang N, Goodfellow M, Zhang LX, Liu ZH. Yuhushiella deserti gen. nov., sp. nov., a new member of the suborder Pseudonocardineae. Int J Syst Evol Microbiol. 2011; 61:621630.

24. Harwani D. Biodiversity of rare thermophilic actinomycetes in the great Indian Thar Desert: An Overview. Indo Am j pharm res. 2013; 3:93499356.

25. Tiwari K, Upadhyay DJ, Mosker E, Sussmuth R, Gupta RK Culturable bioactive actinomycetes from the Great Indian Thar Desert. Ann Microbiol. 2015; 65:1901-1914.

26. Mohammadipanah F, Wink J. Actinobacteria from arid and desert habitats: diversity and biological activity. Front Microbiol. 2015; 6:1541.
27. Hayakawa M, Sadakata T, Kajiura T, Nonomura H. New methods for the highly selective isolation of Micromonospora and Microbispora from soil. J Biosci Bioeng. 1991; 72:320-326.

28. Tamura T, Hayakawa M, Hatano K. A new genus of the order Actinomycetales, Spirilliplanes gen. nov., with description of Spirilliplanes yamanashiensis sp. nov. Int J Syst Evol Microbiol.1997; 47:97-102.

29. Matsukawa E, Nakagawa Y, Iimura Y, Hayakawa M. A new enrichment method for the selective isolation of streptomycetes from the root surfaces of herbaceous plants. Actinomycetologica 2007; 21:66-69.

30. Shirling ET, Gottlieb D. Methods for characterization of Streptomyces species. Int J Syst Evol Microbiol. 1966. 16:313340.

31. Osman HG, Abou-Zeid AA. A technique for the isolation of actinomycetes from soils. J Gen Appl Microbiol. 1968; 14:317319.

32. Lawrance $\mathrm{CH}$. A method of isolating actinomycetes from scabby potato tissue and soil with minimal contamination. Can J Bot. 1956; 34:44-47.

33. Williams ST, Cross T. Isolation, purification, cultivation and preservation of actinomycetes. Method Microbio. 1971; 4:295334.

34. Hayakawa M, Nomura S. Humic acid-vitamin agar, a new medium for the selective isolation of soil actinomycetes. J Biosci Bioeng. 1987; 65:501-509.

35. Cho SH, Hwang CW, Chung HK, Yang CS. A new medium for the selective isolation of soil actinomycetes. J Microbiol Biotechnol. 1994; 22: 561-563.

36. Willoughby LG. Observations on some aquatic actinomycetes of streams and rivers. Freshw Biol.1971; 1:23-27.

37. Vickers JC, Williams ST, Ross GW. A taxonomic approach to selective isolation of Streptomycetes from soil. In: OrtizOrtiz L, Bojalil LF, Yakoleff V (eds) Biological, biochemical and biomedical aspects of actinomycetes. Academic Press, Orland, Florida. 1984; 553-561.

38. Hopwood DA, Bibb MJ, Chater KF, Kieser T, Bruton CJ, Kieser HM, Lydiate DJ, Smith CP, Ward JM, Scrempf H. Genetic manipulation of Streptomyces-A laboratory manual. The John Innes Foundation, Norwich, U.K. 1985; pp 356

39. Kuester E, Williams ST. Selection of media for isolation of Streptomycetes. Nature. 1964; 202:928-929.

40. Eccleston GP, Brooks PR, Kurtboke DI. The occurrence of bioactive micromonosporae in aquatic habitats of the sunshine coast in Australia. Mar Drugs. 2008; 6:243-261.

41. Wayne PA. Clinical and laboratory standards institute. Performance standards for antimicrobial susceptibility testing, 22nd information supplement M100-S22. Clinical and laboratory standards institute. 2012.

42. Srinivasan V, Nagaraja M, Parthasarathi A. Highly deviated asymmetric division in very low proportion of mycobacterial mid-log phase cells.Open Microbiol J. 2014; 8:40-50.

43. Pridham TG, Gottlieb D. The utilization of carbon compounds by some Actinomycetales as an aid for species determination. J Bacteriol. 1948; 56:107-114.

44. Stackebrandt E, Liesack W. Goebel BM Bacterial diversity in a soil sample from a subtropical Australian environment as determined by 16SrDNA analysis. FASEB J. 1993; 7:232-236.

45. Frank JA, Reich CI, Sharma S, Jon S, Weisbaum BA, Gary J, Olsen Tateno Y, Imanishi T, Miyazaki S, Fukami-Kobayashi K, Saitou N, Sugawara H, Gojobori T. Critical Evaluation of Two Primers Commonly Used for Amplification of Bacterial $16 S$ rRNA Genes DNA Data Bank of Japan (DDBJ) for genome scale research in life science. Nucleic Acids Res. 2002; 30:27-30.

46. Wright ES, Yilmaz LS, Noguera DR. DECIPHER, a SearchBased Approach to Chimera identification for 16S rRNA sequences. Appl Environ Microbiol. 2012; 78:717-725.

47. Altschul SF, Madden TL, Schaffer AA, Zhang J, Zhang Z, Miller W, Lipman DJ. Gapped BLAST and PSI-BLAST: a new generation of protein database search programs. Nucleic Acids Res. 1997; 25:3389-3402. 
48. Thompson JD, Gibson TJ, Plewniak F, Jeanmougin F, Higgins DG. The Clustal $\mathrm{X}$ windows interface: flexible strategies for multiple sequence alignment aided by quality analysis tools. Nucleic Acids Res. 1997; 25:4876-4882.

49. Saitou N, Nei M. The neighbour-joining method: a new method for reconstructing phylogenetic trees. Mol Biol Evol. $1987 ; 4: 406-425$

50. Kumar S, Stecher G, Li M, Knyaz C, Tamura K. MEGA X: Molecular Evolutionary Genetics Analysis across computing platforms. Mol Biol Evol. 2018; 201835:1547-1549.

51. Kimura M. A simple method for estimating evolutionary rate of base substitutions through comparative studies of nucleotide sequences. J Mol Evol. 1980;16:111-120.

52. Ayuso-Sacido A, Genilloud O. New PCR primers for the screening of NRPS and PKS-I systems in actinomycetes: detection and distribution of these biosynthetic gene sequences in major taxonomic groups. Microb Ecol. 2005; 49:10-24.

53. Metsa-Ketela M, Salo V, Halo L, Hautala A, Hakala J, Mantsala P, Ylihonko K. An efficient approach for screening minimal PKS genes from Streptomyces. FEMS Microbiol Lett. 1999;180:1-6

54. Marston A. Thin-layer chromatography with biological detection in phytochemistry. J Chromatogr. 2011; 1218:26762683.

55. Lam KS. Discovery of novel metabolites from marine actinomycetes. Curr Opin Microbiol. 2006; 9:245-251.

56. Bull AT, Stach JEM, Ward AC, Goodfellow M. Marine actinobacteria: perspectives, challenges, future directions. Antonie Van Leeuwenhoek. 2005; 87:259-276.

57. Bull AT, Stach JE. Marine actinobacteria: new opportunities for natural product search and discovery. Trends Microbiol. 2007; 15:491-499.

58. Barakate M, Ouhdouch Y, Oufdou K, Beaulieu C. Characterization of rhizospheric soil Streptomycetes from Moroccan habitats and their antimicrobial activities. World J Microbiol Biotechnol. 2002; 18:49-54.

59. Badji B, Riba A, Mathieu F, Lebrihi A, Sabaou N. Antifungal activity of a saharan Actinomadura strain against various pathogenic and toxinogenic fungi. J Med Mycol. 2005; 15(4):211-219.

60. Hozzein WN, Ali MIA, Rabie W. A new preferential medium for enumeration and isolation of desert actinomycetes. World J Microbiol Biotechnol. 2008; 24:1547-1552.

61. Okoro CK, Brown R, Jones AL, Andrews BA, Asenjo JA, Goodfellow M, Bull AT. Diversity of culturable actinomycetes in hyper-arid soils of the Atacama Deserts, Chile. Antonie Van Leeuwenhoek. 2009; 95:121-133.

62. Selvameenal $\mathrm{L}$, Radakrishnan $\mathrm{M}$, Balagurunathan $\mathrm{R}$. Antibiotic pigment from desert soil actinomycetes; biological activity, purification and chemical screening. Indian J Pharm Sci. 2009; 71: 499-504.

63. Meklat A, Sabaou N, Zitouni A, Mathieu F, Lebrihi A. Isolation, taxonomy, and antagonistic properties of halophilic actinomycetes in Saharan soils of Algeria. Appl Environ Microbiol. 2011; 77(18):6710- 6714

64. Williams S. "Genus Streptomyces Waksman and Henrici 1943, 339AL," in Bergey's Manual of Systematic Bacteriology, eds S. T. Williams, M. E. Sharpe, J. G. Holt (Baltimore, MD: Williams \& Wilkins). 1989; 2452-2492.

65. Seo JP, Lee SD. Nocardia harenae sp. nov., an actinomycete isolated from beach sand. Int J Syst Evol Microbiol. 2006; 56:2203-2207.

66. Aria T, Mikami Y. Choromogenecity of Streptomyces. Appl Microbiol. 1972; 23:402-406.

67. Dastager SG, Li WJ, Dayanand A, Tang SK, Tian XP, Zhi XY, $\mathrm{Xu}$ LH, Jiang CL. Separation, identification and analysis of pigment (melanin) production in Streptomyces. Afr J Biotechnol. 2006; 5:134-1139.

68. Getha K, Vikineswary S. Antagonistic effects of Streptomyces violaceusniger strain G10 on Fusarium oxysporum $\mathrm{f}$. sp cubense race 4: Indirect evidence for the role of antibiosis in the antagonistic process. J Ind Microbiol Biotechnol. 2002. 28:303310.

69. Saadoun I, Gharaibeh R. The Streptomyces flora of Badia region of Jordan and its potential as a source of antibiotics active against resistant bacteria. J Arid Environ. 2003; 53:365371.

70. Singh SK, Gurusiddaiah S. Production, purification, and characterization of chandramycin, a polypeptide antibiotic from Streptomyces lydicus. Antimicrob Agents Chemother. 1984; 26(3):394-400.

71. Maheswarappa G, Kavitha D, Vijayarani K, Kumanan. Prodigiosin as anticancer drug Produced from bacteria of termite gut. Indian J Basic App Med. 2013; 3(1):257-266.

72. Balkar N, Korcan E, Malkoc S, Guven K, Erdogmus F. Screening for Antimicrobial Activities of Actinomycetes sp. isolated from Afyonkarahisar, Turkey. Journal of Applied Biological Sciences.2014; 8 (2): 44-49. ISSN: 1307-1130, E-ISSN: 2146-0108, 2014

73. Parthasarathi S, Sathya S, Bupesh G, Samy RD, Mohan MR, Kumar GS, Manikandan M, Kim CJ, Balakrishnan K. Isolation and characterization of antimicrobial compound from marine Streptomyces hygroscopicus BDUS 49. World J Fish Mar Sci. 2012; 4:268-77.

74. Maskey R, Asolkar R, Speitling M, Hoffmann V, GrünWollny I, \& F Fleck W, Laatsch H. Flavones and New Isoflavone Derivatives from Microorganisms: Isolation and Structure Elucidation. Zeitschrift fur Naturforschung B. 2003; 58:686-691.

75. Okami Y, Kitahara T, Hamada M, Naganawa H, Kondo S. Studies on a new amino acid antibiotic, amiclenomycin. J Antibiot. 1974; 27:656-664.

76. Castillo UF, Strobel GA, Mullenberg K, Condron MM, Teplow DB, Folgiano V, Gallo M, Ferracane R, Mannina L, Viel S, Codde M, Robison R, Porter H, James Jensen J. Munumbicins E-4 and E-5: novel broad-spectrum antibiotics from Streptomyces NRRL 3052. FEMS Microbiol Lett. 2006; 255(2):296-300. 